\title{
Монголын угсаатны зүйн судалгаа ба орчин үе (= Этнографические исследования в Монголии на современном этапе)
}

\section{Цэрэнханд Гэлэгжамиын ${ }^{1}$, Маралмаа Нагаанбуу}

${ }^{1}$ Институт истории и этнологии Академии наук Монголии (д. 13, пр. Мира, район Баянзурх, 13330 Улан-Батор, Монголия)

Ph.D., профессор

E-mail: n.marlaa1@gmail.com

${ }^{2}$ Институт истории и этнологии Академии наук Монголии Монголии (д. 13, пр. Мира, район Баянзурх, 13330 Улан-Батор, Монголия)

Ph.D., старший научный сотрудник

E-mail: n.marlaa1@gmail.com

(C) КалмНЦ РАН, 2020

(C) Цэрэнханд Г., Маралмаа Н., 2020

Аннотация: Цель статьи - осветить основные итоги этнографических исследований в Монголии. Основой для этнографических исследований Монголии явилось появление профессиональных ученых в конце 1950-х гг., развитие исследовательских методологий и формирование главных направлений в исследованиях. С середины 1960-х гг. возобладал новый подход к этнографическим исследованиям, и началось исследование эволюции традиционной кочевой скотоводческой культуры в Монголии. Можно отметить, что в этот период появляются работы по культурной антропологии. При этом кочевая культура и обычаи того времени были описаны формально, с выделением исторического периода. Анализ работ этого периода показывает: методология исследования основывалась на том, что реальность жизни основана на исходном материале и остается этнокультурным фактом, который никогда не теряет своей ценности. В течение последующих десятилетий основным направлением монгольских этнографических исследований являлись, во-первых, изучение образа жизни монгольских этнических групп, а во-вторых, выявление причин культурных и этнических изменений. Активно проводились систематические этнографические исследования по таким вопросам, как животноводство, кочевые обычаи, поселения и жилища, пища, молочные продукты, одежда, семья и брак, религия, ремесла и фольклор. Результаты. В настоящее время можно отметить, что происходит развитие теоретических исследований, основанных на достигнутых ранее научных результатах. Полевые методы исследования этнографии, социальной и культурной антропологии становятся все более сложными, а область изучения культурного наследия монгольского народа приобретает все большее значение. 
Ключевые слова: Монголия, этнографические исследования, методология, исследователи, экспедиции, социальная и культурная антропология, этнические группы

Благодарность. Материалы статьи апробированы на Международной научной онлайн-конференции «Монголоведение в начале XXI в.: современное состояние и перспективы развития-ІІ», проведенной при финансовой поддержке РФФИ (проект № 2009-22004) и частичной поддержке гранта Правительства РФ (№ 075-15-2019-1879).

Для цитирования: Цэрэнханд Г., Маралмаа Н. Монголын угсаатны зүйн судалгаа ба орчин үе (= Этнографические исследования в Монголии на современном этапе) // Монголоведение. 2020. Т. 12. № 3. С. 468-480. (На монг.). DOI: 10.22162/2500-15232020-3-468-480

UDC 39

DOI: $10.22162 / 2500-1523-2020-3-468-480$

\title{
Contemporary Ethnographic Studies of Mongolia
}

\section{Tserenkhand Gelegzhamtsin ${ }^{1}$, Maralmaa Nagaanbuu ${ }^{2}$}

${ }^{1}$ Institute of History and Ethnology of the Academy of Sciences of Mongolia (13, Mira Ave., Bayanzurkh Distr., Ulan Bator 13330, Mongolia)

Ph.D., Professor

E-mail: n.marlaa1@gmail.com

${ }^{2}$ Institute of History and Ethnology of the Academy of Sciences of Mongolia (13, Mira Ave., Bayanzurkh Distr., Ulan Bator 13330, Mongolia)

Ph.D., Senior Researche Associate

E-mail:n.marlaa1@gmail.com

(C) KalmSC RAS, 2020

(C) Tserenkhand G., Maralmaa N., 2020

\begin{abstract}
Goals. The article aims to highlight the main results of ethnographic research in Mongolia. The basis for ethnographic studies in Mongolia was laid by the emergence of professional scientists in the late 1950s, development of research methodologies, and the formation of the main research directions. Since the mid-1960s, a new approach to ethnographic research has prevailed, and studies in the evolution of traditional nomadic pastoral culture in Mongolia began. It can be noted that during this period there were works on cultural anthropology. At the same time, the nomadic culture and customs of that time were described formally, with an emphasis on the historical period. The study of works from this period allows us to conclude that the research methodology was based on the fact that the reality of life rested on the source material and remained an ethnocultural fact that never lost its value. During the following decades, the main focus of Mongolian ethnographic research was, firstly, the study of the way of life of Mongolian ethnic groups, and secondly, the identification of the causes of cultural and ethnic changes. Systematic ethnographic research was actively conducted on various issues, such as animal husbandry, nomadic customs, settlements and dwellings, food, dairy products, clothing, family and marriage, religion, crafts and folklore. Results. Currently, the following can be noted. There is a development of theoretical research based on previously achieved scientific results. Field research methods
\end{abstract}


of ethnography, social and cultural anthropology are becoming more complex, and the field of studying the cultural heritage of the Mongolian people is becoming more important.

Keywords: Mongolia, ethnographic research, methodology, scientists, expeditions, social and cultural anthropology, ethnic groups

Acknowledgements. The article was presented at the international scientific online conference "Mongolian Studies at the beginning of the 21st century: Current State and Development Prospects - II", held with the financial support of RFBR (project № 20-09-22004) and partial support of the Russian Government Grant (№ 075-15-2019-1879).

For citation: Tserenkhand G., Maralmaa N. Contemporary Ethnographic Studies of Mongolia. Mongolian Studies (Elista). 2020. Vol. 12. No. 3. Pp. 468-480. (In Mong.). DOI: 10.22162/2500-1523-2020-3-468-480

\section{Өмнөх үг}

Дэлхий дахины хэмжээнд даяарчлагдах үйл явц эрчимжихэд угсаатны зүй, хүн судлалын ухааны сэдэв улам нарийсч, дүгнэлттэй хандах, ажиглалтын аргыг хэрэглэж ард түмний амьдрал ахуй, соёлын гүнд орж аливаа ёс заншил, зан үйлийн үүсэл, хувислыг олж тодотгох таатай нөхцөл бүрдэж судалгааны чиг баримжаа нээгдсэн гэж үзэж болно.

Энэхүү салбар шинжлэх ухаан нь тухайн ард түмний амьдрах орчин, мэдлэг сэтгэхүйд суурилан нийгэм, соёлын олон асуудлыг тал бүрээс нь авч үзэж нэгэн бүхэллэг зүйлийг шинжлэх ухаануудын заагт шийдэж өнгөрсөн, одоо, ирээдүйг харах боломжийг бүрдүүлдэг билээ. ШУА-ын Түүх угсаатны зүйн хүрээлэнгийн угсаатны зүйн судалгааны түүх бол монголчуудын угсаа-гарвал, нийгэм соёлоос эхэлж, түүхч эрдэмтэд, тухайлбал Ж. Цэвээн, Х. Пэрлээ, Ш. Нацагдорж, Г. Сүхбаатар, Д. Гонгор нарын бүтээл туурьвилд үндэслэгдэж, улмаар аж ахуй, өв соёлын талаар бичигдсэн сэдвүүд нь Г. Бадрах, Б. Ренчин, Y. Ядамсүрэн, Я. Цэвэл болон олон арван соён гэгээрүүлэгч эрдэмтэн судлаачийн нэртэй шууд холбогдож байлаа.

1950-аад оны сүүл үе гэхэд мэргэжлийн судлаачид төрөн гарч, судалгааны арга зүй боловсруулагдаж, судалгааны чиг баримжаатай болсон явдал тухайн салбар ухааны хөгжлийн эх суурь юм. Энэ үеэс монгол угсаатны бүлэг Дархад, Түрэг хэлтэн уйгар- цаатангуудын талаар нэгэн сэдэвт С. Бадамхатаны бүтээлүүд [Бадамхатан 1962; Хөвсгөлийн Дархад ястан 1965] хэвлэгдэн олны хүртээл болж, угсаа гарал, өв соёлын тухай асуудлыг угсаатны зүйн Үүднээс хэрхэн томъёолж судалдаг аргачлалын хэмжээнд авч үзсэн эрдэм шинжилгээний ач холбогдлоос нь үүдэн монгол овогтны угсаа-гарвалын тухай асуудалд судлаачид анхаарлаа хандуулах явдал өргөжиж ирсэн байна.

1960 оны дунд үеэс угсаатны зүйн судалгааны чиглэлд шинэлэг хандлага зонхилох болж, Монголын нүүдэлч малчдын уламжлалт соёлын хувьсал өөрчлөлтийн талаарх судалгаа эхэлсэн түүхтэй. Тухайн үед нүүдэл соёл, зан заншлыг улируулан авч үзэхээсээ илүү байдалчлан бичиглэж түүхэн цаг үеийг тодотгож байсан явдал, соёлын хүн судлалын эхлэл байжээ хэмээн ойлгох боломжтой ба судалгааны арга зүйн хувьд амьдралын бодит байдлыг эх материалд тулгуурлах хандлага зонхилж, хэзээ ч үнэ цэнээ алдахгүй угсаасоёлын баримт болон үлдэж байгаа нь судалгааны бүтээлүүдээс тодорхой байна. Монголын угсаатны судалгааны үндсэн чиглэл нь нэгд, монгол 


\section{Этнология и антропология}

угсаатны «нийтлэг» бүлгүүдийн ахуй байдал, аж амьдралын хэв маягийг судалж, түүнээсээ улируулан уламжлалыг олж мэдэх, хоёрт, ард түмний дунд өрнөж байгаа соёлын өөрчлөлт, ялангуяа үндэсний агуулгатай соёлын үүсэн тогтож буй учир шалтгааныг тодруулахыг чухалчилж, тухайлбал мал аж ахуй, нүүдэллэх журам, хот айл, орон сууц, хоол унд, цагаан идээ, хувцас болон гэрлэлт, сүсэг бишрэл, гар урлал, ардын мэдлэг зэрэг асуудлаар угсаатны зүйн системтэй судалгаа явагдаж байв. Энэ нь 1976 онд хуралдсан МАХН-ын XVII их хурлаас дэвшүүлсэн социалист аж төрөх ёсыг хэвшүүлэх талын заалттай уялдуулан нийгмийн хөгжил нэгдэлч малчдын аж амьдралд хэрхэн нөлөөлж, шинэ үеийн ахуй бүрэлдэн тогтож буй үйл явцыг судлах оролдлого хийгдэж хэд хэдэн нэгэн сэдэвт бүтээлүүд нийтлэгдэж [Цэрэнханд 1972; Цэрэнханд 1982; Цэрэнханд 1989; Батнасан 1978], малчдын мал маллагааны уламжлалт арга, нүүдлийн хэлбэрийг хангай, тал хээр, говийн бүсээр судалж, нийтлэг болон өвөрмөц онцлогийг тодруулж харьцуулан дүгнэх, тэрчлэн өрх гэр, гэр бүлийн асуудал бол угсаатны зүйн ухааны үндсэн сэдвийн нэг болох учир түүний шинж төрхөөр тухайн хөгжлийн түвшин илэрхийлэгддэг хэмээн ойлгож, тухайн хөгжлийн тусгал болохуйц аж төрөх ёсыг хэвшүүлэх, шинэ хүнийг төлөвшүүлэх гэх мэт үзэл суртал хүмүүжлийн асуудлыг хэрэгжүүлэх ач холбогдолтойг харгалзан монгол гэр ахуйн хүрээнд хамрагдах гол гол сэдвийг хөндөж, урьд өмнө төдийлөн судлагдаж шийдэгдээгүй сэдвүүдийг судалгааны хэрэглэгдэхүүнд үндэслэн сэдэж тавьсанд оршино. Мөн тухайн үеийн нийгмийн амьдралд шинэ баяр ёслол төлөвшиж, улмаар хэв заншил бүрэлдэн тогтож буй явцыг түүхчлэн угсаа-нийгэм судлалын талаас эрдэм шинжилгээний нэлээд өгүүлэл, Х. Нямбуугийн нэгэн сэдэвт бүтээлүүд хэвлэгдсэн нь угсаатны зүйн ухааны салбарт гарсан шинэлэг судалгаа байлаа [Нямбуу 1976].

1970-аад оноос монгол угсаатны хөгжлийн явцтай холбогдох асуудлыг нэгтгэн дүгнэхийг оролдож эхэлсэн болно. Эдгээр судалгаанд угсаатны хөгжлийн нийтлэг ба өвөрмөц тал нийгэм соёлын хөгжилд хэрхэн нөлөөлж буй байдал, хэтийн хандлага зэрэг асуудлыг хөгжлийн түвшинтэй уялдуулан хөндөж тавьсан байна. Иймээс тухайн үед малчдын уламжлалт аж ахуй, нийгмийн хөгжлийн дагуу хэрхэн шинэчлэгдэж, ямар хэлбэрээр өөрчлөгдөн хувирч байгааг судлах нь эрдэм шинжилгээний ач холбогдолтой асуудал байв. Энэ чиглэлээр хамтын бүтээл бичигдэж [Орчин цагийн 1982] монгол угсаатны хөгжлийн явцыг угсаатны ухамсар, угсаа-бүлгүүдийн уламжлалт соёлд гарч буй хувьсал, угсаа нийгмийн нийтлэг бүрэлдэн тогтсон зэрэг асуудлуудтай холбож, ард түмний амьдралд гарсан өөрчлөлтийг тодруулах оролдлого байв.

Угсаатны гол хэмжүүр бол нийгмийн хөгжлийн үр дүнд угсаа гарал өөр буюу нэг угсаатай олон нийтлэг өөр хоорондоо харилцан ижилсэх, нийлэх гэсэн хоёр үзэгдэл болно. Угсаатны ухамсар эсвэл яс үндсийн хамаарлын тухай ойлголт бол хүн төрөлхтний үүсэл гарлын үеэс уламжлагдсан нийгмийн үзэгдэл бөгөөд үндэстэн нэгэнт бүрэлдэн тогтсон монгол орны хувьд түүнд үйлчилж байсан нийгэм эдийн засгийн үндэс нэгэнт алга болж, тэрхүү ойлголт нь зөвхөн уламжлалын хэлбэрээр хүмүүсийн ухамсарт үлдэж байсан ч угсаатны бүлгүүдийн хоорондын нэгдэл нягтрал нь хурдсаж, үндэстний нэгдмэл хөгжил гүнзгийрч байгаа талаар тухайн үеийн угсаатны явцыг дүгнэжээ. 
Ерөнхийлбэл Монгол угсаатны бүлгүүдийн соёл нь угтаа нэгэн үндэстэй боловч хожмоо байгаль цаг уурын зохицол, засаг захиргааны өөрчлөлт зохион байгуулалт зэргээс үүдэлтэй өөр хоорондоо харилцан ялгаатай салбарлаж нэр нэршил хэл аялгууны хэд хэдэн төрөл болон төлөвшсөн ч эргээд нийтлэг хэлбэрт шилжин хөгжихөд онцын төвөг үгүй гэж болно. Монгол угсаатны явц нь нэгд, угсаа бүлгүүдийн хоорондын ижилсэлт, хоёрт, нийгэм, эдийн засаг, соёлын амьдралын бүх хэсэгт нэгдэж байгаагаар тодорхойлогдож, монголын утга зохиолын хэл нийт бүлгүүдийн үндсэн хэл болж хувирсан явдал орон нутгийн ба нийтлэгүүдийн ялгааг арилган нийгмийн нэг төрөл соёл бүрэлдэн тогтоход зонхилох үүрэг гүйцэтгэж буй билээ. Тухайн үед утга зохиол, уран сайхны урлаг мэргэшлийн биеэ даасан хэмжээнд хөгжиж, нийт ард түмний уламжлалт оюуны соёлд эсрэг нөлөө үзүүлж, улмаар тэр нь үндэсний соёлын хөгжилд эргэн үйлчилж, түүний цаашдын хөгжлийг гүнзгийрүүлэх боломж өгч, хүмүүсийн ухамсар дахь өнгөрсөн нийгмийн заншил зуршлыг шинэ үеийн зан суртахууны соёлоор солих өөрөөр хэлбэл шинэ хүний төрх шинжийг бие хүнд төлөвшүүлж хэвшүүлэхэд зохих үүрэг гүйцэтгэж, угсаа соёлын нийтлэг бүрэлдэхэд шийдвэрлэх хүчин зүйл болж байжээ. Ийнхүү хөгжлийн явц нь монгол угсаатны бүлгүүдийн дунд нэгдмэл соёл бүрэлдэн тогтоход зохих нөлөө үзүүлж нийгмийн хөгжлийн явцыг түргэтгэхэд аятай нөхцлийг буй болгож байв хэмээн тухайн үеийн угсаа-соёлын үйл явцыг дүгнэж болохоор байв.

Угсаатны судалгааны зорилго 1980-аад оноос монголчуудын угсаа-түүх, соёлын уламжлалыг гүнзгийрүүлэн судлахад чиглэгдэж ихэнх аймаг сумдад хээрийн судалгаагаар ажиллаж, нутгийн онцлог ба угсаа бүлгүүдийн оюуны болон эд өлгийн соёлын нийтлэг, өвөрмөц талыг тодруулж, улируулан авч үзсэн болно. Үүнтэй уялдуулан тэмдэглэхэд, угсаатны гол шинж болох хүмүүсийн ухамсар ба ахуй амьдралд хадгалагдан үлдсэн соёлын зарим элемент, ялангуяа хэв заншил, зан үйлийн зүйл тухайн угсаатны бүлэг болон орон нутгийн хэмжээгээр уламжлагдан байх нь аль ч нийгмийн үед үргэлжлэх бөгөөд Үүний ашигтай талыг агуулга хэлбэрээр нь баяжуулан нийт үндэсний соёлын хүртээмж болгон угсаа бүлгүүдийн харилцан ойртолт ижилсэх явцын мөн чанарыг хүн ардын ухамсарт шингээх явдал угсаатны зүйн ухааны судалгааны нэгэн зорилт байж болох билээ.

Монголын уламжлалт нүүдлийн аж ахуй бол бусад угсаатан ард түмнээс ялгагдах нэг гол шинж бөгөөд монголчууд хэзээнээс Төв Азийн аж ахуйсоёлын хэв маягт хамаарагдан тал хээрийн бүсийн мал аж ахуй эрхэлсээр иржээ. Нүүдэлчин монголчууд мал аж ахуйгаa эрхлэх талаар олон зуун жилийн туршлага хуримтлуулсан ба чухамхүҮ энэ арга ажиллагаа нь нийгмийн хөгжлийн дагуу шинэчлэгдэн шилжилтийн байдалд орсон ч энэ бүгдтэй холбогдуулан Түүхийн хүрээлэнгийн угсаатан судлаач эрдэмтдийн туурвисан Монгол улсын угсаатны зүй 3 боть хамтын бүтээлд [Монголын угсаатны зүй 1987; Монголын угсаатны зүй 1996а; Монголын угсаатны зүй 1996б] оролцогч судлаач эрдэмтэд: С. Бадамхатан, Г. Цэрэнханд, Г. Батнасан, Ц. Аюуш, Д. Тангад, Т. Дисан, Д. Нансалмаа, Л. Жамсран, Г. Мэнэс, И. Лхагвасүрэн, Г. Гантогтох, Г. Золбаяр нар угсаатны бүлгүүдийн бүтэц овог ясны үүсэл, төлөвшил, аж ахуй, зан заншил соёлын талаархи үндсэн асуудлыг хөндөж, 


\section{Этнология и антропология}

хээрийн судалгаа явуулж, бодит амьдралыг гүнээс нь харж, эх хэрэглэгдэхүүн цуглуулж эрдэм шинжилгээний эргэлтэнд оруулж өгсөн явдал гадаад, дотоодын судлаачдын анхаарлыг зүй ёсоор татдаг. Үүнтэй холбогдуулан хэлэхэд Монгол угсаатны бичил бүлгүүдийн угсаа гарвал, соёл, түүх, зан заншлын асуудлыг аман түүх, бичмэл эх материал, судалгааны бүтээлүүдтэй харьцуулан судалж урьд өмнө тодорхойгүй байсан угсаа хамаадал, уламжлалт соёлын зарим асуудлаар нотлон батлах санаа дүгнэлтийг дэвшүүлсэн явдал угсаатан судлалын салбарын томоохон ололтын нэг гэж болно. Зохиогчид угсаа-бүлгийн судалгааны асуудалд шинэлэг арга зүйн хэлбэрээр хандаж, нутаг нутгийн өвөрмөц онцлог ба нийтлэг талыг бодит байдлаар илэрхийлэн дүгнэлт өгөхөд гол анхаарлаа хандуулсан явдал энэхүҮ бүтээлийн шинэлэг бөгөөд эрдэм шинжилгээний ач холбогдлыг өндөржүүлсэн цаашдын судлгааны эхлэл болсон юм. Тэрчлэн Төв Азийн нүүдэлчдийн соёлд монгол түмний оруулсан хувь нэмрийг тод гаргаж, XIX-XX зууны үеийн нүүдэлч малчдын аж төрөх байдал, мал маллагааны уламжлал, хувьслын олон талын асуудлыг судалсан нь Монголын өв соёлыг олон түмэнд танин мэдүүлэх, хойч үедээ уламжлуулахад шинжлэх ухааны суурь судалгаа болсон бүтээл гэдгийг тэмдэглэж болно.

1990 оны сүүлээс тус салбар нь сэдэвчлэн судлах чиглэлийг баримталж хэд хэдэн бүтээлийг олны хүртээл болгосон ба угсаатны зүйн судалгааны нэг онцлог нь «сэдэвт» болон «төсөл»-ийн хүрээнд судалгааны ажлуудыг хийж гүйцэтгэжээ. Тухайлбал, С. Бадамхатаны удирдсан Монгол-Японы хамтарсан «Гурван гол» төсөл, «Ойрад монголчуудын угсаа гарал, түүх соёл, хэл аялгуу, аман зохиол» судлах «Алтай I, II, III» төсөл, А. Очирын удирдсан «Монголчуудын уг эх» төсөл, Г. Цэрэнхандын удирдсан «Монгол угсаатны угсаа-соёлын өв уламжлал», «Угсаатны судлал, нийгэм соёлынүндсэн асуудал» зэрэгтөслүүдхэргэжсэн болно. Тухайлбал, «Эрт дундад үеийн монголчуудын аж ахуй, соёл» сэдэвт ажил нь Төв Азийн ард түмний нүүдэл иргэншлийг улируулан гүнзгийрүүлэхэд чиглэгдэж судалгааны үндсэн дээр монгол хэлтний нийтлэг үүсэж бүрэлдсэн, салж холдсон он цаг, үйл явцын зарим тодруулгыг хийсэн болно. Төв Азийн нүүдэлчид болон дундад эртний монголчуудын уламжлалт соёл салшгүй холбоотойгоор үүсэн хувьсаж, хөгжлийн олон зуун жилийн замыг туулж өнөөгийн өнгө төрхөө олжээ. Эртний монголчуудын аж ахуй, соёлд хөрш зэргэлдээ нүүдэлчин аймгууд, түүнчлэн Хятад, Дундад Ази зэрэг суурьшмал орны соёлын нөлөө багагүй хэмжээгээр тусгагдсан хэдий ч монголчуудын бүтээж ирсэн эд өлөг, оюуны соёл нь өөрийн түүхэн онцлогтой хөгжиж ирснийг тодруулах оролдлого хийгджээ. Монгол нутагт иргэншсэн нүүдэлчин монголчуудын бүтээсэн соёл бол малчин хүний өдөр тутмын үйл ажиллагаа болох мал аж ахуйн бүтээгдэхүүнийг боловсруулан амьдрал ахуйдаa хэрэглэх үйл явцын шууд тусгал билээ. Гэр зуурын үйлдвэрлэлийг дотор нь цагаан идээ болон эсгий хийх, малын арьс шир, үс хялгасыг боловсруулан бүтээгдэхүүн үйлдвэрлэх гэсэн үндсэн хэсгүүдэд хуваан үзэв. Монголчуудын нүүдэл амьдралын гол утга болсон ардын язгуур мэдлэг болон орон сууцны сэдвийг мал аж ахуйгаа хөтлөн явуулах, байгальтай оршин зохицохуй, нутаг бэлчээр сонгох нүүдэллэн аж төрөхүй зэрэг арга ухааны ҮҮднээс тодотгосон. ЭнэхүҮ бүтээлийг бичихэд доктор Л. Билэгт, Г. Цэрэнханд, С. Өлзийбаяр, Б. Баатархүү, Б. Бадмаа-Оюу, Б. Отгонбаатар, Д. Эрдэнэбаатар нар оролцсон байна. 
«Угсаатан судлал» хэмээх эрдэм шинжилгээний цуврал бичигт (1959 оноос эхлэн одоо хүртэл нийт XXVII боть бүтээл) монголчуудын угсаа-түүх, нүүдэл иргэншил, аж ахуйтай холбогдох сэдвээр олон арван сонирхолтой бүтээл, өгүүллүүд хэвлэгдсэн байна.

Монголын угсаатны зүйн судалгааны чиглэлээр гадаадын эрдэмтэд дорвитой ажил хийсээр ирсэн билээ. Үүнд, Монголчуудын дунд угсаатны зүйн тодорхой судалгаа хийсэн эрдэмтэдээс Зөвлөлтийн угсаатны зүйч К.В. Вяткина [Вяткина 1960] бөгөөд тэрбээр 1949 онд Монгол Зөвлөлтийн археологи-угсаатны зүйн хамтарсан шинжилгээний ангид оролцон «БНМАУын монголчууд» хэмээх судалгааны бүтээл бичиж, түүндээ Монголын зарим нутгийн соёлын уламжлалыг угсаатны онол арга зүйд тулгуурлан тоочин бичих аргаар өгүүлсэн нь угсаатны судлалд зохих хувь нэмэр оруулсан юм. Мөн 1960-аад оны сүүл үе гэхэд Монгол-Зөвлөлтийн түүх-соёлын хамтарсан судалгааны шинэ эхлэл тавигдсан болно. ЭнэхүҮ хамтарсан шинжилгээний ангид Зөвлөлтийн талаас Л.Л. Викторова [Викторова 1980], Н.Л. Жуковская [Жуковская 1977; Жуковская 1990; Жуковская 1992; Жуковская 2002], А.М. Решетов [Решетов 1985; Решетов, Васильевский, Волков 1986; Решетов 1986а; Решетов 1986б; Решетов 1987], А.Е. Пахутов [Пахутов 1983а; Пахутов 1983б; Пахутов 1989; Пахутов 1990] зэрэг эрдэмтэд ажиллаж, нэгэн сэдэвт зохиолууд, эрдэм шинжилгээний өгүүлэлүүд нийтлэгджээ. Уг шинжилгээний явцад Л.Л. Викторова «Монголчууд» (соёлын уг эх) [Викторова 1980] бүтээлдээ Төв Азийн нүүдэлчдийн түүх, түүний дотор монголчуудын угсаа гарвалыг тусгайлан судалсан цөөн эрдэмтдийн нэг юм. Түүний судалгааны голлох сурвалж нь Монгол нутгаар явж өөрөө цуглуулсан этнографийн хээрийн шинжилгээний хэрэглэгдэхүүн, мөн эртний ба дундад үеийн бичгийн сурвалжууд, ардын аман зохиолын дурсгалууд болно. Эдгээр хэрэглэгдэхүүн, сурвалжуудтай хамтруулан түүх, археологи, этнографи, хэл шинжлэл, антропологийн чиглэлээр судалсан бусад судлаачдын бүтээлүүдийг харьцуулан нэгтгэх замаар судалгааг хийсэн байна. Тэрбээр монгол угсаатны түүхийг авч үзэхдээ, орчин үеэс угсаатны нийтлэг үүсэхийн өмнөх үе хүртлэх түүхийн бүх шатыг хамруулахыг зорьжээ. Судалгааных нь үндсэн чиглэл бол эдийн соёл бөгөөд уг судлах зүйлийн гурван тулгуур хэмээн хоол хүнс, хувцас, орон сууцыг хамтруулан хүннү, түрэг, монголын үеэр харьцуулан шинжилсэн нь сонирхолтой юм. Оюуны соёлын хүрээнд ардын аман зохиол, шашин шүтлэгийн элемент, он цагийн тоолол, хэл шинжлэлийн судалгааг харьцуулсан нь иж бүрэн шинж чанартай болж монгол судлаачдаас өндөр үнэлгээ авчээ. Н.Л. Жуковская [Жуковская 1990; Жуковская 1992; Жуковская 2002] бол Монгол судлал, Монголын угсаатны зүйн чиглэлээр бүтээлээ туурвиж 20 гаруй удаа Монголд ирж угсаатны зүйн хээрийн судалгаагаар ажиллаж, арвин хэрэглэгдэхүүн цуглуулж эрдэм шинжилгээннй эргэлтэнд оруулсан нь дэлхийн монголч эрдэмтдийн хүртээл болж, монголын угсаатны зүйн чиглэлийн судалгаанд жинтэй хувь нэмэр болсон юм. Түүний бүтээлүүдэд Монголын ард түмний уламжлалт оюуны хийж, монгол малчдын заншил, түүний дотор өнгө, тооны бэлгэдэл ба шашны зан үйлийг анх удаа эрдэм шинжилгээний тогтолцоонд оруулсан шинэлэг бөгөөд олны анхаарлыг татсан шинжлэх ухааны бүтээл хэмээн монголч эрдэмтэд үнэлдэг байна. Мөн Зөвлөлтийн урлаг 


\section{Этнология и антропология}

судлаач Н.В. Кочешковын “Монгол хэлтэн ард түмний чимэглэлийн урлаг” (XIX-XX), “Монгол ардын урлаг” [Кочешков 1973; Кочешков 1979] зэрэг судалгааны зохиолууд хэвлэгдэж олны хүртээл болгосон нь угсаатны зүйн судалгааны сонирхолтой ажлын нэг юм.

Монголын угсаатны зүйн олон асуудлаар гадаадын эрдэмтэд судалгаа явуулсны дотор Америкийн нэрт эрдэмтэн О. Латтиморын хөдөөгийн нүүдэл амьдралыг харуулсан 1975 оны баримтад кинонууд, Японы эрдэмтэн Онукагийн малчдын нүүдэл соёлыг жилийн дөрвөн улиралаар Өвөрхнгай, Баянхонгор аймгуудын зарим сумдын жишээгээр зураглаж кино хальснаа буулгаж олонд толилуулсан явдал судлаачдын дунд онцгой үнэлгээ авч байгаа зэргийг тэмдэглэх нь чухал.

1970-аад оны эхэн үеэс Монголын угсаатны зүйн судалгааны арга зүйд Польшийн нийгэм-социологийн үүднээс судалдаг хандлага нэвтэрч ирсэн ба энэ үед Польшийн эрдэмтэн профессор Дыновски С., Соколович Д., Шинкевич С., Васильевски Е. нарын оролцсон хамтарсан угсаатны зүйн судалгаа ихэвчлэн Ойрад монголчуудын дунд явагдсан ба Монголын талаас эрдэмтэн Х. Нямбуу, Самбуу, Д. Тангад нар хамтран ажиллаж, эрдэм шинжилгээний бүтээл өгүүллүүдийг олны хүртээл болгосон байна.

Мөн сүүлийн жилүүдэд Соёлын биет бус өвийн судалгааг амжилттай явуулж 2010 оноос Оюу Толгой төслийн хүрээнд Өмнөговь аймгийн Ханбогд, Манлай, Баян-Овоо, Даланзадгад зэрэг сумуудад 10 гаруй удаагийн хээрийн судалгаа хийгээд байна. Энэхүу соёлын өвийн судалгаа нь Монгол улсад угсаатны биет бус соёлын өвийн судалгааг өргөжүүлэхэд томоохон түлхэц болж байна. Тэр дундаа угсаатны зүйн мэргэжлийн судлаачид хэрэгжүүлж байгаа нь тус судалгааны ач холбогдолыг өндөрсгөхөд тодорхой хэмжээгээр нөлөө үзүүлж байна. Үүнээс гадна тус салбар судалгааны арга зүй, чиг хандлагаа өргөжүүлж, гадаад, дотоодын судалгааны байгууллага, хүрээлэнгүүдтэй хамтарсан судалгаа, шинжилгээг явуулж байна. Үүнд ОХУ-ын Тува улсын Хүмүүнлэгийн судалгааны хүрээлэн, Буриадын их сургууль, Буриадын хүмүүнлэгийн хүрээлэн, Япон улсын Шига Мужын их сургууль, Англи улсын Кембрижийн их сургуулийн Монгол, Дотоод Ази судлалын төв гэх мэт олон улсад нэр хүнд бүхий сургууль, хүрээлэнгүүдтэй хамтарч ном бүтээлүүдийг олны хүртээл болгож байна.

Ард түмний амьдралын бодит байдлыг зураглан гаргаж өгдөгөөрөө угсаатны зүйн хээрийн судалгаа үнэтэй бөгөөд үр өгөөжтэй болж, нийгмийн шинжлэх ухааны хүрээнд тулгуур эх хэрэглэгдэхүүнийг бүрэлдүүлэхийн зэрэгцээгээр сурвалжийн үүргийг ч гүйцэтгэх ач холбогдолтой юм.

Монголын угсаатны зүйн хээрийн судалгаагаар 1960 оноос 1990 он хүртэл ажилласан эрдэмтэд судлаачдын хуримтлуулсан эх хэрэглэгдэхүүнийг Кембрижийн их сургуулийн багш, профессор Урадын Э. Булагтай хамтран арван ботиор хэвлэн нийтлэж олны хүртээл болгосон явдал цаг үеэ олсон чухал ажил болов. Тухайлбал, аливаа асуудлыг дотроос нь олж дүгнэх баримтжуулах болон нийгмийн хөгжлийн түвшин, улс хоорондын харилцаа холбоотой уялдан угсаатны ухамсарт үсрэнгүй өөрчлөлт гарч буй эдүгээ үед судалгааны асуудалд хандах чиглэлийг бодолцох шаардлага амьдралаас урган гарч байгаа билээ. Судалгааны арга зүйд тулгуурлан нэгтгэсэн хээрийн судалгааны хэрэглэгдүүн 
нь эрдэм шинжилгээний үүднээс эх сурвалж болдог тухай тодотговол: Судлаач хүн нүдээр үзэж, чихээр сонсож, биеэр оролцож гэмээж бодит үнэнийг бүтээх чадвар нь эх бичиг, түүхийн тодорхой үеийн баримт болон бичгийн сурвалжийг хянаж батламжлах боломж олгоно. Тэрчлэн судалгааны аман мэдээ нь үнэт зүйлс байдаг учир тухайн нутагт буюу угсаа-бүлгийн дунд харьцангуй урт хугацаанд амьдарч, ахуй байдлыг дотроос нь ажигласан судлаачийн асуулга лавлагааны эх хэрэглэгдэхүүн нь сурвалжийн хэмжээнд хүрдэг байна.

\section{Дүгнэлт}

Эрдэм шинжилгээний үр дүнд тулгуурлаж онолын чиг баримжаа хөгждөг учир зүйг харгалзан угсаатны зүй, нийгэм, соёлын хүн судлалын хээрийн судалгааны арга зүй чамбайрч, монгол түмний өв соёлын судалгааны чиглэл улам улам чухалчлагдаж байгааг тэмдэглэх хэрэгтэй гэж бодно.

1985 оноос Угсаатны зүйн сектор болон өргөжиж 1995 оноос секторын эрхлэгчээр профессор Г. Цэрэнханд ажиллаж эхэлсэн ба 2006 онд тус сектор нь зохион байгуулалтын хувьд өөр хэлбэрт орж «Угсаатан судлалын салбар» болон өргөжсөн байна. Энэ үеэс Г. Цэрэнхандын удирдлагын дор «Монгол угсаатны угсаа-соёлын өв уламжлал» сэдвийн хүрээнд Г. Цэрэнханд «Монголчуудын ураг төрлийн тогтолцоо», Т. Дисан «Уламжлалт гар урлал (арьсан урлал)», Б. Отгонбаатар «Малчдын нүүдэл, нүүдэллэх уламжлал» зэрэг тус тус судалгааны ажил хийж Хүрээлэнгийн гар бичмэлийн санд шилжүүлсэн байна. Мөн «Монгол угсаатны түүхэн хөгжлийн явц» сэдвийн хүрээнд судалгааны ажил явагдаж, үүний үр дүнд «Эрт, дундад үеийн монголчуудын аж ахуй, соёл» [Эрт, дундад үеийн 2006] хамтын бүтээл, Л. Билэгт «Раннемонгольские племена» [Билэгт 2007] нэгэн сэдэвт зохиол зэргийг туурвисан байна. Сүүлийн жилүүдэд Д. Бум-Очир «Улс төрийн хүн судлалын онолын үүд» [Бум-Очир 2008], О. Отгонбаатар «Монголчуудын оршуулгын зан үйл (XX зуун)» [Отгонбаатар 2009], Г. Цэрэнханд «Монголчуудын ураг төрөл: ёс заншил, зан үйл» [Цэрэнханд 2015], «Монголын улсын тувачууд» [Баатархүү 2017], С. Чулуун, Д. В. Ивановын эмхтгэсэн «Монгол орон ба монголчууд» [Монгол орон ба монголчууд 2015] зэрэг нэгэн сэдэвт бүтээлүүдийг туурвин гаргаад байна.

Тус салбар нь 2008 оноос Угсаатан судлал, антропологийн салбар болон өргөжиж, дэлхийн жишигт нийцүүлэн, судалгааны арга зүй, чиг хандлагаа өөрчлөн ажиллах болов. 2015 онд тус салбарын 30-н жилийн ой тохиосон бөгөөд тус ойн хүрээнд салбарыг Нэрт угсаатны зүйч С. Бадамхатаны нэрэмжит болгосон бөгөөд «Угсаатны судалгааны салбар» болгон хуучин нэрэнд өөрчлөлт оруулсан болно.

Харин 2019 оны 10-р сараас хүрээлэнгийн бүтцэд өөрчлөлт орж ТүҮх угсаатны зүйн хүрээлэн нэртэйгээр үйл ажиллагаагаа явуулах болсон юм. Энэ үеэс угсаатны зүйн салбар Хэрэглээний угсаатан судлал, биет бус соёлын өвийн төв, Угсаатан судлал, нийгэм соёлын хүн судлалын салбар болон өргөжин, үйл ажиллагаагаа явуулж байна.

\section{Ном зүй}

Баатархүу 2017 - БаатархүY Бат-Өлзийн. Монгол улсын тувачууд: угсаа-соёлын судалгаа. Ред. С. Чулуун. Улаанбаатар: Адмон принт, 2017. 387 х. 


\section{Этнология и антропология}

Бадамхатан 1962 - Бадамхатан С. Хөвсгөлийн цаатан ардын аж байдал. Улаанбаатар: ШУАХ, 1962. 66 х.

Батнасан 1978 - Батнасан Г. БНМАУ дахь нэгдэлчдийн аж ахуйгаа хөтлөх арга ажиллагаа [Этнографийн судалгаа]. Улаанбаатар: ШУАХ, 1978. 118 х.

Билэгт 2007 - Билэгт. Раннемонгольские племена. Улаанбаатар: Цоморлигтов ХХК, 2007. $222 \mathrm{c}$.

Бум-Очир 2008 - Бум-Очир Д. Улс төрийн хүн судлалын онолын үүд. Улаанбаатар: Бемби сан, 2008. 198 х.

Викторова 1980 - Викторова Л. Л. Монголы: Происхождение народа и истоки культуры. М.: Наука, 1980. 224 с.

Вяткина 1960 - Вяткина К. В. Монголы Монгольской Народной Республики (Материалы историко-этнографической экспедиции Академии наук СССР и Комитета наук МНР 1948-1949 гг.) // Восточно-азиатский этнографический сборник. Труды ИЭ. Новая серия. Т. 60. М.; Л.: Изд-во Акад. наук СССР. [Ленингр. отд-ние], 1960. С. $159-271$.

Жуковская 1977 - Жуковская Н. Л. Ламаизм и ранние формы религий. М.: Наука, 1977. $199 \mathrm{c}$.

Жуковская 1990 - Жуковская Н. Л. Судьба кочевой культуры. Рассказы о Монголии и монголах. М.: Наука. ГРВЛ, 1990. 112 с.

Жуковская 1992 - Жуковская Н. Л. Категории и символика традиционной культуры монголов. М.: Наука, 1992. 194 с.

Жуковская 2002 - Жуковская Н. Л. Кочевники Монголии: Культура. Традиции. Символика. М.: Вост. лит., 2002. 274 с.

Кочешков 1973 - Кочешков Н. В. Народное искусство монголов. М.: ГРВЛ, Наука, $1973.200 \mathrm{c}$.

Кочешков 1979 - Кочешков Н. В. Декоративное искусство монголоязычных народов XIX - середины XX века. М.: Искусство, 1979. 206 с.

Монгол орон 2015 - Монгол орон ба монголчууд. Эмхтгэсэн: С. Чулуун, Д. В. Иванов. Улаанбаатар: Адмон принт, 2015. 368 с.

Монгол улсын угсаатны зүй 1987 - БНМАУ-ын угсаатны зүй. I боть. Улаанбаатар: Улсын хэвлийн газар, 1987. 432 т.

Монгол улсын угсаатны зүй 1996а - Монгол улсын угсаатны зүй. II боть. Ойрадын угсаатны зүй. Улаанбаатар: Улсын хэвлэлийн газар, 1996. 437 т.

Монгол улсын угсаатны зүй 19966 - Монгол улсын угсаатны зүй. ІІІ боть. Буриад, барга, үзэмчин, дарьганга, хотон, тува цаатан, тува малчин, хамниган ястнуудын угсаатны зүй. Улаанбаатар: Улсын хэвлэлийн газар, 1996. 392 т.

Нямбуу 1976 - Нямбуу Х. Өнөөгийн монгол ёс. Улаанбаатар: ШУАХ, 1976. 237 х.

Орчин цагийн 1982 - Орчин цагийн угсаатны явц ба социалист аж ахуй // Угсаатан судлал. Т. VIII. Улаанбаатар: ШУАХ, 1982. 88 х.

Отгонбаатар 2009 - Отгонбаатар Б. Монголчуудын оршуулгын зан үйл (XX зуун). Улаанбаатар: Монгол, 2009. 194 х.

Пахутов 1983а - Пахутов А. Е. Монгольская гэр, ее этнические особенности и эволюция (по материалам экспедиции 1983 г. в МНР). // Всесоюзная сессия по итогам полевых этнографических и антропологических исследований, 1982-1983 гг.: Тезисы докладов. Черновцы, 1984. Ч. 2. С. 402-403.

Пахутов 19836 - Пахутов А. Е. Связь системы питания монголоязычных народов с их хозяйственно-культурным типом // Материальная и духовная культура калмыков: сб. науч. ст. Элиста: КНИИИФЭ, 1983. С. 27-36.

Пахутов 1989 - Пахутов А. Е. Традиции «Цагаан сар» у монголов // Обычаи и обряды монгольских народов. Элиста: КНИИ ИФЭ, 1989. С. 29-35. 
Пахутов 1990 - Пахутов А. Е. Традиционная одежда дэрбэтов МНР // Всесоюз. научн. сессия по итогам полевых этнографических и антропологических исследований 1988-1989 гг. Тез. докл. Алма-Ата, 1990. Ч. 1. С. 104-105.

Решетов 1985 - Решетов А. М. Основные задачи и первые итоги совместных советско-монгольских этнографических исследований // Древние культуры Монголии. Новосибирск: Наука. Сиб. отд-ние, 1985. С. 210-214.

Решетов, Васильевский, Волков 1986 - Решетов А. М., Васильевский Р. С., Волков В. В. Советско-монгольская историко-культурная экспедиция // Общественные науки. 1986. № 4. С. 203-208.

Решетов 1986 - Решетов А. М. Современные этнокультурные процессы у народов Восточной Монголии // Всесоюзная сессия по итогам полевых этнографических и антропологических исследований 1984-1985 годов: Тез. докл. Йошкар-Ола, 1986. C. 271-272.

Решетов 19866 - Решетов А. М. Этнографические исследования в Монголии в 1985 г. // Известия СО АН СССР. Новосибирск, 1986. Серия истории, филологии и философии. № 14. Вып. 3. С. 63-66.

Решетов 1987 - Решетов А. М. Изучение этнографии и антропологии монголов // Советское монголоведение (1917-1987). М.: ГРВЛ, 1987. С. 96-108.

Хөвсгөлийн Дархад ястан 1965 - Хөвсгөлийн Дархад ястан. Улаанбаатар: ШУАХ, 1965. 257 c.

Цэрэнханд 1972 - Цэрэнханд Г. Хөдөө аж ахуйн нэгдэлч малчдын өрх гэр, гэр ахуй. Улаанбаатар: ШУАХ, 1972.

Цэрэнханд 1982 - Цэрэнханд Г. Нэгдэлчдийн аж байдал. Улаанбаатар: ШУАХ, 1982. Цэрэнханд 1989 - Цэрэнханд Г. Обычай «гэр бурэх» у монголов // Обычаи и обряды монгольских народов. Элиста: КНИИ ИФЭ, 1989. С. 23-28.

Цэрэнханд 2015 - Цэрэнханд Г. Монголчуудын ураг төрөл: ёс заншил, зан үйл._.лаанбаатар: Адмон принт ХХК, 2015. 144 х.

Эрт, дундад үеийн 2006 - Эрт, дундад үеийн Монголчуудын аж ахуй, соёл. Улаанбаатар: Цөмөрлигтөв, 2006. 151 х.

\section{References}

Ancient and Medieval Mongols: Economy and Culture. Ulaanbaatar: Tsomorligtov Co. Ltd., 2006. 151 p. (In Mong.)

Baatarkhüü B.-Ö. Tuvans of Mongolia: Ethnocultural Studies. S. Chuluun (ed.). Ulaanbaatar: Admon Print, 2017. 387 p. (In Mong.)

Badamkhatan S. Life of Khövsgöl Tsaatans. Ulaanbaatar: Mongolian Academy of Sciences, 1962. 66 p. (In Mong.)

Batnasan G. Collective farming in the Mongolian People's Republic. In: Ethnographic Studies. Ulaanbaatar: Mongolian Academy of Sciences, 1978. 118 p. (In Mong.)

Bilegt L. Earliest Mongolian Tribes. Ulaanbaatar: Tsomorligtov Co. Ltd., 2007. 222 p. (In Russ.)

Bum-Ochir D. Theory of Political Anthropology: An Introduction. Ulaanbaatar: Bembi San, 2008. 198 p. (In Mong.)

Chuluun S., Ivanov D. V. (comps.) Mongolia and Mongols. Ulaanbaatar: Admon Print, 2015. 368 p. (In Mong.)

Contemporary ethnocentrism and Socialist economy. In: Ethnology. Vol. 1. Fasc. 1. Ulaanbaatar: Mongolian Academy of Sciences, 1982. 88 p. (In Mong.)

Ethnography of Mongolia. Vol. 2: Ethnography of Oirats. Ulaanbaatar: State Publ. House, 1996. 437 p. (In Mong.) 


\section{Этнология и антропология}

Ethnography of Mongolia. Vol. 3: Ethnography of Buryats, Barga, Üzemchin, Dariganga, Khoton, Reindeer (Tsaatan) Tuvans, Livestock Tuvans, Khamnigans. Ulaanbaatar: State Publ. House, 1996. 392p. (In Mong.)

Ethnography of the Mongolian People's Republic. Vol. 1. Ulaanbaatar: State Publ. House, 1987. 432 p. (In Mong.)

Kocheshkov N. V. Decorative Arts of Mongolic Peoples: $19^{\text {th }}-$ Mid-20 $0^{\text {th }}$ Centuries. Moscow: Iskusstvo, 1979. 206 p. (In Russ.)

Kocheshkov N. V. Mongolian Folk Arts. Moscow: Nauka - GRVL, 1973. 200 p. (In Russ.)

Nyambuu Kh. Contemporary Mongolian Rites. Ulaanbaatar, 1976. (In Mong.)

Otgonbaatar B. Mongolian Funeral Rites: $20^{\text {th }}$ Century. Ulaanbaatar, 2009. (In Mong.)

Pakhutov A. E. Coherence between the food system of Mongolic peoples and their economic-cultural framework revisited. In: Material and Spiritual Culture of Kalmyks. Collected Scholarly Papers. Elista: Kalmyk Research Institute of History, Philology and Economics, 1983. Pp. 27-36. (In Russ.)

Pakhutov A. E. Dorbets of the MPR: traditional garments. In: Summarizing Results of 19881989 Ethnographic and Anthropological Studies. All-Union Session. Theses. Alma-Ata, 1990. Vol. 1. Pp. 104-105. (In Russ.)

Pakhutov A. E. The Mongolian ger, its ethnic peculiarities, and evolution: a case study of materials collected during the 1983 expedition to the MPR. In: Summarizing Results of 1982-1983 Ethnographic and Anthropological Studies. All-Union Session. Theses. Chernovtsy, 1984. Vol. 2. Pp. 402-403. (In Russ.)

Pakhutov A. E. Traditions of Tsagaan sar and the Mongols. In: Customs and Rites of Mongolic Peoples. Elista: Kalmyk Research Institute of History, Philology and Economics, 1989. Pp. 29-35. (In Russ.)

Reshetov A. M. Contemporary Soviet-Mongolian ethnographic studies: basic objectives and first outcomes. In: Ancient Cultures of Mongolia. Novosibirsk: Nauka, 1985. Pp. 210-214. (In Russ.)

Reshetov A. M. Ethnographic studies in Mongolia: 1985. Izvestiya SO AN SSSR. Ser.: History, Philology and Philosophy. 1986. Vol. 14. No. 3. Pp. 63-66. (In Russ.)

Reshetov A. M. Mongols: (a review of) ethnographic and anthropological studies. In: Mongolian Studies in the Soviet Union (1917-1987). Moscow: Nauka - GRVL, 1987. Pp. 96-108. (In Russ.)

Reshetov A. M. Peoples of Eastern Mongolia: contemporary ethnocultural processes. In: Summarizing Results of 1984-1985 Ethnographic and Anthropological Studies. AllUnion Session. Theses. Yoshkar-Ola, 1986. Pp. 271-272. (In Russ.)

Reshetov A. M., Vasilyevsky R. S., Volkov V. V. Soviet-Mongolian Historical and Cultural Expedition. Obshchestvennye nauki. 1986. No. 4. Pp. 203-208. (In Russ.)

The Khövsgöl Darkhad. Ulaanbaatar: Mongolian Academy of Sciences, 1965. 257 p. (In Mong.)

Tserenkhand G. Ger burekh: the Mongolian rite revisited. In: Customs and Rites of Mongolic Peoples. Elista: Kalmyk Research Institute of History, Philology and Economics, 1989. Pp. 23-28. (In Russ.)

Tserenkhand G. Herders in Collective Farms: Households and Subsidiary Husbandries. Ulaanbaatar: Mongolian Academy of Sciences, 1972. (In Mong.)

Tserenkhand G. Mongolian kinship system: customs and rites. Ulaanbaatar: Admon Print, 2015. 144 p. (In Mong.)

Tserenkhand G. Well-Being of Collectives. Ulaanbaatar: Mongolian Academy of Sciences, 1982. (In Mong.)

Viktorova L. L. Mongols: Origins of the People and Roots of Their Culture. Moscow: Nauka, 1980. 224 p. (In Russ.) 
Vyatkina K. V. Mongols of the Mongolian People's Republic: materials of the 1948-1949 joint expedition by the Soviet Academy of Sciences and Mongolia's Science Committee. In: East Asian Ethnographic Collection. Vol. 60. Moscow; Leningrad: USSR Academy of Sciences, 1960. Pp. 159-271. (In Russ.)

Zhukovskaya N. L. Lamaism and Early Forms of Religion. Moscow: Nauka, 1977. 199 p. (In Russ.)

Zhukovskaya N. L. Nomads of Mongolia: Culture, Traditions, Symbols. Textbook. Moscow: Vostochnaya Literatura, 2002. 274 p. (In Russ.)

Zhukovskaya N. L. The Destiny of Nomadic Culture: Essays on Mongolia and Mongols. Moscow: Nauka - GRVL, 1990. 112 p. (In Russ.)

Zhukovskaya N. L. Traditional Mongolian Culture: Categories and Symbols. Moscow: Nauka, 1992. 194 p. (In Russ.) 